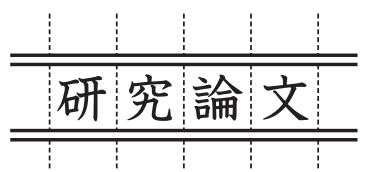

\title{
チタニヤ系フラックス入りワイヤを用いた立向上進マグ溶接現象
}

\section{MAG Welding Phenomena with Titania-Based Flux Cored Wire in Vertical Upward Position}

\author{
細井宏一*・平田好 則**・荻野洋 輔**・河野秀規** \\ Koichi HOSOI, Yoshinori HIRATA, Yosuke OGINO and Hideki KOUNO
}

(Received November 18 2015)

\begin{abstract}
In recent years, gas shielded arc welding processes with flux cored wire have been widely used in many industrial sectors because of various advantages in fabrication: weldability, productivity, etc. In this study, MAG welding phenomena with titania-based flux cored wire were experimentally investigated in comparison with those with solid wire. In the vertical upward position, feasible operation range of welding current and welding speed was examined for both wires of flux cored wire and solid wire. Through the observation of high speed photography, dynamic behaviors of droplet transfer and molten pool were clarified and discussed in MAG welding with titania-based flux cored wire. Melting temperature of the titania- based slag was confirmed to be higher than that of mild steel by using differential thermal analysis (DTA). It is found that the molten metal at the wire tip is transferred along the flux pillar to weld pool in flux cored wire welding. The slag of higher melting temperature solidifies ahead of metal and supports liquid metal in the weld pool in the vertical upward position.
\end{abstract}

Key Words: FCAW, Titania-based Flux, Solid Wire, Metal Transfer Phenomena, Weld Pool, Surface Tension, Weldability

\section{1. 緒言}

アーク溶接技術は、約 100 年前に被覆アーク溶接棒の実 用化が始まって以来、鋼材を用いる工業製品や各種構造物 の接合加工技術として発展し続けている。その中でもマグ 溶接や炭酸ガスアーク溶接などのガスメタルアーク (GMA) 溶接は、高能率で、自動化・ロボット化に適する溶接法と して各種産業分野の製造工程で多用されている。GMA 溶 接では溶接ワイヤと母材との間でアーク放電を発生させ、 溶接を行うもので、ワイヤが溶融する速度が大きいため、 単位時間当たりの母材への溶着量が多く、高能率な溶接が できること 1,2)、ワイヤがパックやスプールから連続的に供 給されるので、溶接作業が途切れることがないこと、など の特長がある。特に、チタニヤ系のフラックス入りワイヤ は、姿勢溶接に扔いても溶融池を維持できることなどから、 1980 年頃から造船業界を中心に適用が始まった。このチ夕 二ヤ系を主とするフラックス入りワイヤは、船舶・海洋構 造物分野だけでなく、今では化学プラントや橋梁など産業 界で広く使用されており 羊,4)、国内全業種への適用では、被 覆アーク溶接棒やソリッドワイヤ、サブマージ溶接用溶材 などの各種溶接材料の中で、出荷量ベースで $30 \%$ を超え る品種構成比を占めるに至っている5)。

本研究では、フラックス入りワイヤについて、その最も
大きな特徴といえる全姿勢での良好な溶接作業性を可能に している因子 の,7)を明らかにすることを目的に、立向上進 姿勢での溶融池現象と溶滴移行現象をとりあげ、ソリッド ワイヤの溶接現象との差異を比較検討しながら実験・観察 し、その機構を検討した。

\section{2. 供試材料および試験方法}

\section{1 供試材料}

実験には、JIS Z3313:2009「軟鋼、高張力鋼及び低温用鋼 用アーク溶接フラックス入りワイヤ」に準拠するフラック ス入りワイヤ（T 49J 0 T1-1 C A-U/旧 YFW-C50DR 該当品） を用いた。また、JIS Z3312:2009「軟鋼、高張力鋼及び低温 用鋼用のマグ溶接及びミグ溶接ソリッドワイヤ」に準拠す るソリッドワイヤ（YGW12 該当品）を溶接現象の比較の ために使用した。シールドガスには、マグ溶接用混合ガス $\left(\mathrm{Ar}-20 \% \mathrm{CO}_{2}\right)$ を用いた。供試鋼板は軟鋼板 SS400 (12 mm × $70 \mathrm{~mm} \times 430 \mathrm{~mm})$ を用い、グラインダーやバタリングなど の表面処理は行っていない。

\section{2 試験方法}

2.2.1 ビードオンプレート溶接

フラックス入りワイヤ並びにソリッドワイヤを用いた溶 接試験は、Table 1 に示す溶接条件の範囲で行った。溶接

*(一社) 日本溶接協会 事業部（广 101-0025 東京都千代田区神田佐久間町 4-20）

The Japan Welding Engineering Society Qualification \& Certification department (4-20 Kanda Sakuma, Chiyoda, Tokyo, 101-0025 Japan)

**大阪大学大学院工学研究科 マテリアル生産科学専攻 (下 565-0871 大阪府吹田市山田丘 2-1)

Division of Materials and Manufacturing Science, Graduate School of Engineering, Osaka University (2-1 Yamadaoka, Suita, Osaka, 565-0871 Japan) 
Table 1 Welding condition in vertical upward position

\begin{tabular}{|c|c|c|c|c|c|}
\hline $\begin{array}{c}\text { Wire } \\
\text { diameter }\end{array}$ & Current & Voltage & $\begin{array}{c}\text { Welding } \\
\text { speed }\end{array}$ & $\begin{array}{c}\text { Shielding } \\
\text { gas }\end{array}$ & $\begin{array}{c}\text { Electrode } \\
\text { manipulation }\end{array}$ \\
\hline $1.2 \mathrm{~mm}$ & $140-250 \mathrm{~A}$ & $17-25 \mathrm{~V}$ & $<180 \mathrm{~cm} / \mathrm{min}$ & $\begin{array}{c}\text { Ar- } 20 \% \mathrm{CO}_{2} \\
251 / \mathrm{min}\end{array}$ & Straight \\
\hline
\end{tabular}

ロボットを用いて、ストレート運棒によりビードオンプ レート溶接を行い、立向上進姿勢での溶接現象を調べた。

2.2.2 高速度ビデオカメラによる観察

ビードオンプレート溶接時のアーク中での溶滴状況と、 アーク直下の溶融池の状況を観察するため、高速度ビデオ カメラ（ナックイメージテクノロジー社製 MEMRECAM RX-6）を用いた。これらアーク近傍の現象を可視化するに あたり、アーク光やヒュームの影響を低減するために、980 $\mathrm{nm}$ バンドパスフィルタを使用して撮影を行った。また、照

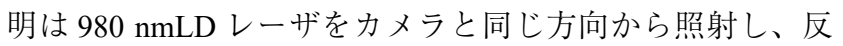
射光を撮影した。このため、高速度ビデオカメラによる観 察はモノクロ画像となる。なお、撮影コマ数は $2000 \mathrm{fps}$ と し、シャッター速度と絞りは観察対象に応じて適切に選択 した。また、溶接部全体を撮影することを目的に、デジタ ルカメラ（ニコン製 D3100）も使用した。

2.2 .3 立向上進溶接の評価

Table 1 に示す溶接条件範囲で実施した立向上進姿勢に おいて、ワイヤ先端に形成される溶滴形状や移行状況、溶 融池の形状や流動状態を高速度ビデオカメラで撮影・観察 するとともに、ビードオンプレート溶接によって形成され るビード外観の状態を視覚により官能評価した。

\section{3. 実験結果}

\section{1 立向上進溶接の適用範囲}

Fig.1にフラックス入りワイヤを用いたときの立向上進 姿勢での溶接が可能となる条件範囲とビード外観の例を示 す。実験では溶接電流と溶接速度を変え、得られた溶接ビー ドの外観から溶接の可否を判定した。ビード外観の良否は、 主として余盛形状の連続性で判断している。Fig.1(b)に示 すようにハンピングや垂れ落ちによってビード形状が不連 続となった場合を不可（ロ）とし、一部に不整な箇所が見 られるビード形状を限界条件 $(\triangle)$ としている。Fig.2にソ リッドワイヤを用いた場合の実験結果を示す。いずれのワ イヤの場合も溶接速度を高めると、ハンピングやアンダー カット状の欠陥が発生し、正常ビードを得ることができな い。一方、溶接電流を高めると、垂れ落ち現象が顕著になり、 ハンピング状のビード外観を呈する。とりわけソリッドワ イヤの場合、190 A を超えると垂れ落ちが著しくなり、立 向溶接が溶接速度に関わらず不可能になることが分かる。

3.2 立向上進溶接の高速度ビデオカメラによる観察

Fig.3に立向上進溶接におけるワイヤ先端の溶滴、アーク、

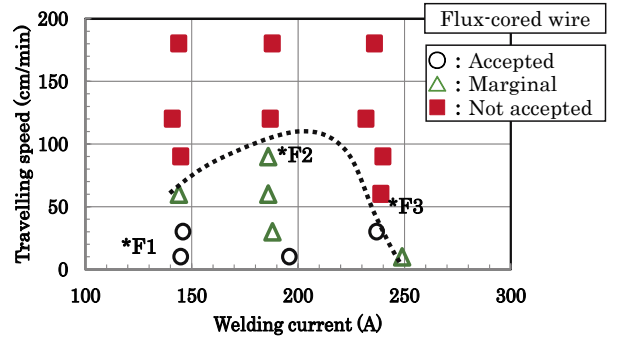

(a) Applicable condition map of welding current and welding speed
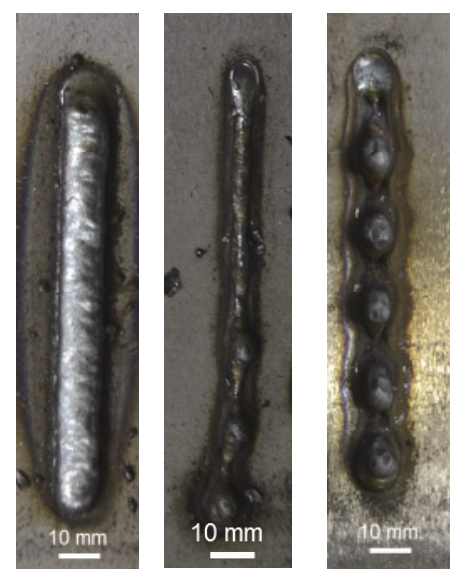

F1:O

F2: $\triangle$

F3 :

(b) Bead appearances at F1,F2,F3 points

Fig.1 Feasible operation range with flux-cored wire.

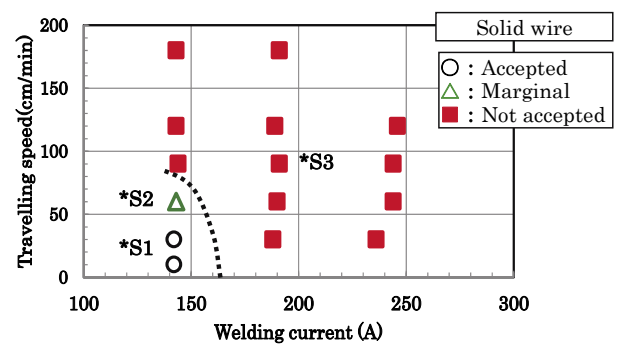

(a) Applicable condition map of welding current and welding speed

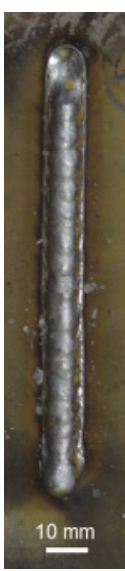

S1 : $\bigcirc$

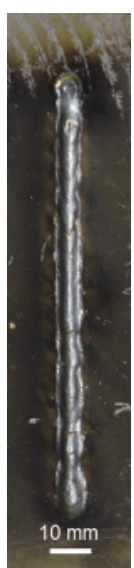

$\mathrm{S} 2: \triangle$

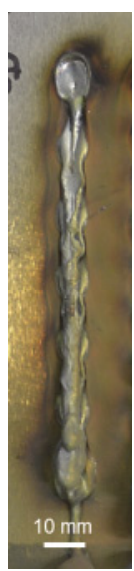

S3 : (b) Bead appearances at $\mathrm{S} 1, \mathrm{~S} 2, \mathrm{~S} 3$ points

Fig.2 Feasible operation range with solid wire. 


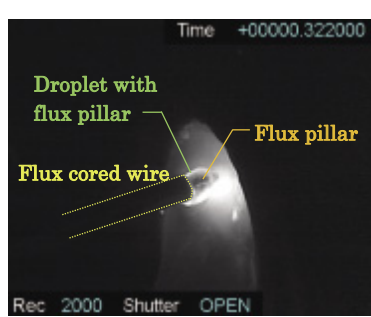

(a) Flux cored wire

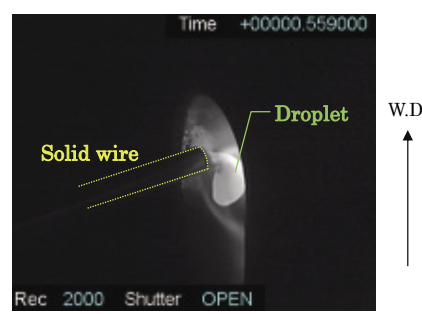

(b) Solid wire
Fig.3 Droplet transfer phenomena of flux cored wire and solid wire.

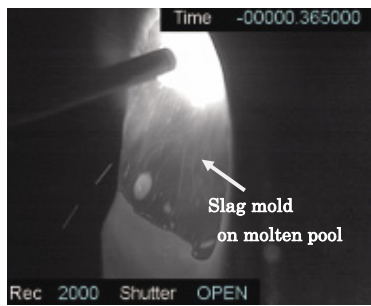

(a) Flux cored wire

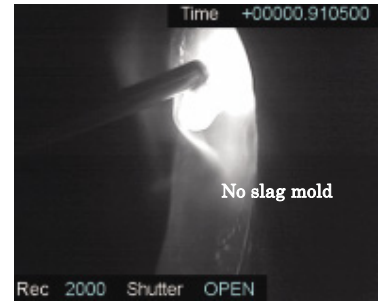

(b) Solid wire
Fig.4 Phenomena on the molten pool of flux cored wire and solid wire.

溶融池の状態を示す。(a)(b) はそれぞれフラックス入りワ イヤ、ソリッドワイヤの場合である。写真から、立向上進 溶接が可能なフラックス入りワイヤにおいては、ワイヤ先 端にフラックス柱が形成されており、溶滴がそのフラック ス柱の表層を伝うようにして溶融池側へ移行していること が分かる。また、その溶滴サイズもソリッドワイヤに比べ ると小さく見える。さらに、フラックス入りワイヤのほう が溶融池に広がりがあって、溶融金属が盛り上がる傾向が あり、母材に溶融金属がなじむ状況が確認できた。

Fig.4には溶融池を観察するために、カメラ狙い位置を Fig.3よりもやや下側に向けて撮影した観察例を示す。なお、 溶融池の状況を鮮明に撮影するため、カメラレンズの絞り をやや開いているので、アーク部分が露光量過多となって いる。Fig.4(a) に示すようにフラックス入りワイヤの場合、 アークの進行方向の後行部でスラグ層が溶融金属に覆いか ぶさるように追随しており、鋳型のように溶融池の溶湯を 支えている。以下、このような鋳型 (Mold) のように溶融池 を保持する現象をモールド効果と呼ぶ。一方、Fig.4(b)に 示すソリッドワイヤの場合、溶湯が重力により溶融池から 流れ落ちている様子が分かる。

Fig.5 は、立向上進姿勢において、溶滴と溶融池を含む 溶接アーク近傍の全体状況を、フレームレート $24 \mathrm{fps}$ で撮 影した連続写真である。フラックス入りワイヤの場合、溶 融池がスラグのモールド効果によって覆われており、垂れ 落ちせずにビードを形成しながら、アークに追随していく 様子が分かる。一方、ソリッドワイヤの場合、溶融池が表

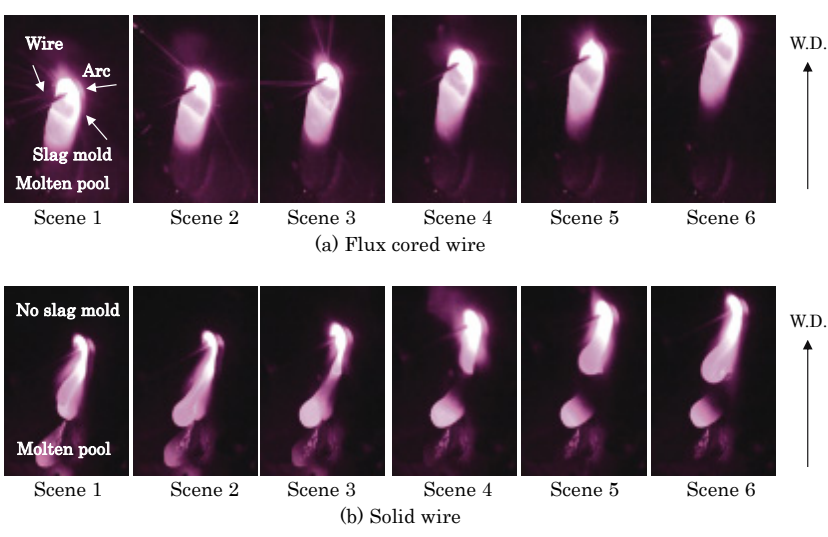

Fig.5 Bead formation process by flux cored wire and solid wire.
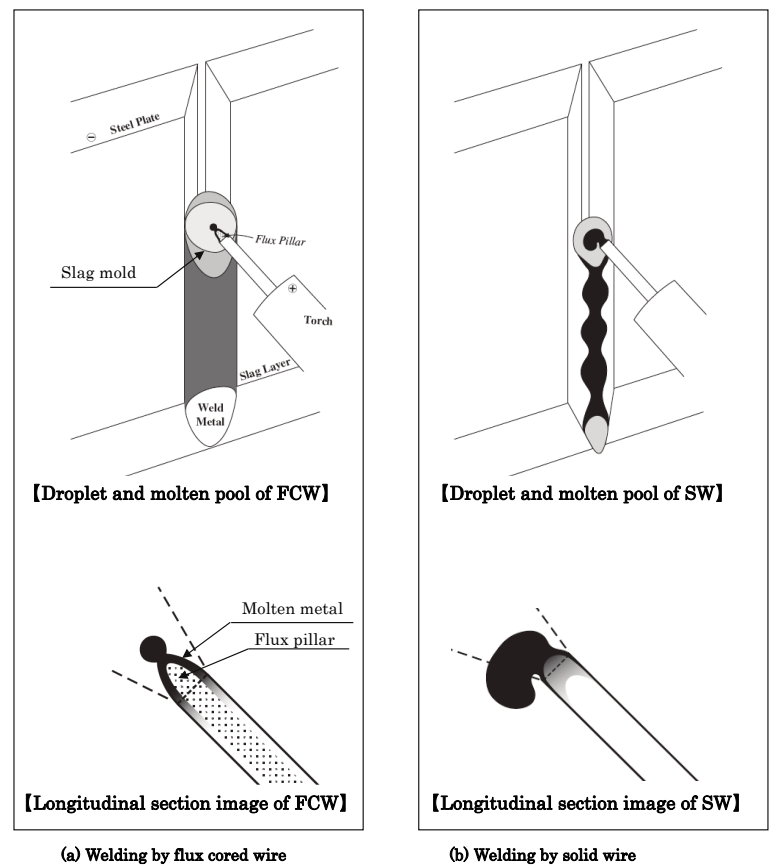

Fig.6 Schematic illustration of droplet transfer and molten pool during welding.

面張力などの自己懸垂力だけではアーク点に追随すること が出来ずに垂れ落ちを生じ、連続したビード形成ができて いない様子が分かる。

これらの観察結果から、フラックス入りワイヤとソリッ ドワイヤのそれぞれに関し、立向上進姿勢における溶滴移 行と溶融池の状況を模式的に描くと Fig.6のようになる。 すなわち、立向で安定した溶接を行うためには、まず、ワ イヤ先端から溶融池へ溶滴が確実に移行できる機構が必要 である。本研究で対象としているフラックス入りワイヤ を用いた場合、Fig.6(a)に示す如くワイヤ先端の溶融金属 が、フラックス柱を伝うようにして溶融池の表面に近づい て溶滴を形成して移行していく。ソリッドワイヤの場合、 
Fig.6(b)のように大きな溶滴が、懸垂できるフラックス柱 のような芯も無いままに、半溶融状態となったワイヤ先端 に形成されて移行する。また、ソリッドワイヤのグロビュー ル移行では比較的大きな溶滴が形成されるため、重力の作 用により溶融池へ安定した移行をすることができない。さ らに、溶融池については、表面を包み込むモールド効果を 出現させる表層のスラグの有無が、立向上進などの姿勢溶 接の可否を決定づけている。これらの溶滴移行とモールド 効果の両面から、フラックス入りワイヤでは姿勢溶接が可 能になっていることが確認できた。

\section{4. 考察}

上述したビードオンプレートでの試験結果から、チタニ ヤ系フラックス入りワイヤが立向上進溶接を可能にする理 由として、次の $2 つ の$ 事項が考えられた。

1) 溶湯単独での懸垂能力では立向上進姿勢は溶融池を保持 できないが、発生したスラグが立向で溶融池表面を覆っ て垂れ落ちを防止するモールド効果を有する。

2) ワイヤ先端で形成された溶融金属が、フラックス柱に 沿って溶融池へ移行することで、確実に溶接金属を形成 する。

そこで、溶湯の懸垂能力とフラックスの性質に関して、 考察を行う。

\section{1 溶湯の表面張力による溶融池の懸垂能力}

一般的にチタニヤ系フラックス入りワイヤは、その溶鋼 中の酸素量が高いことが知られている。Fig.7に示すように、 溶鋼中の酸素量は表面張力を著しく変化させる ${ }^{8)-10)}$ 。一方、 チタニヤ系フラックス入りワイヤは、製品設計上、多量の 酸化物フラックスが含まれている。そのため、溶鋼中の酸 素量を低減する目的から強脱酸剤が投入されているが 11),12)、 動的な現象である溶接プロセスでは、溶融金属の酸素量は

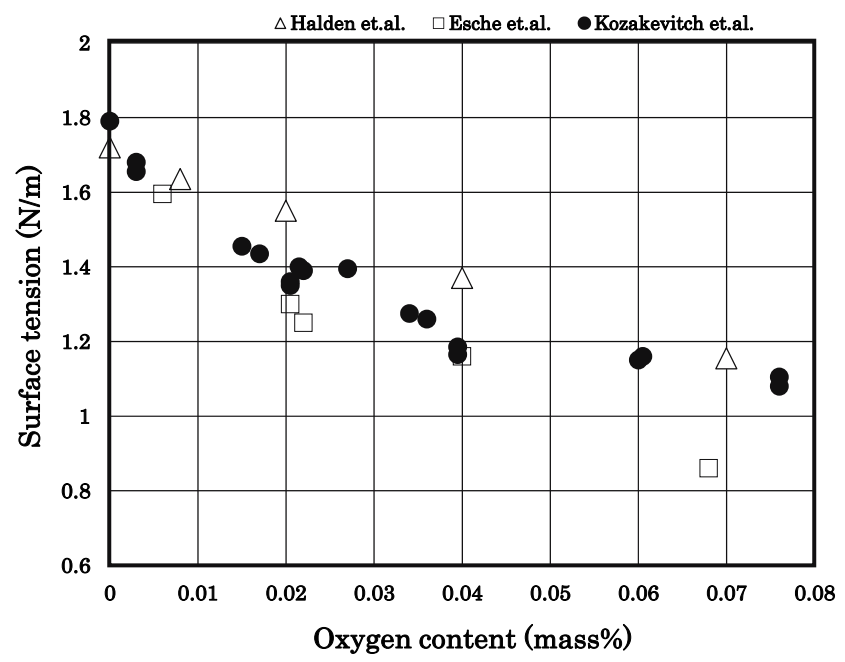

Fig.7 Influence of oxygen content on surface tension of molten steel.
空間的にも時間的にも大きく変化し、溶鋼の表面張力も大 きく変動していると考えられる。

ここでは考察を進めるにあたって、溶融金属の表面張力 が、酸素の影響や溶湯の温度の影響を受けず一定である と仮定し、スラグ生成による影響を除外して、溶湯の表面 張力だけで立向溶接が可能か否かの検討を行った。そこ で、溶融池内流動と表面変形を考慮した数值モデル ${ }^{13)}$ を用 いて、溶融金属の表面張力と溶接速度をパラメータとして ビード形成現象を検討した。本モデルではアークから母材 に流入する入熱と電流、溶融池に作用するアーク圧力をガ ウス分布とし、熱量を有する球状溶滴が一定の移行周波数 で溶融池に飛び込むものと仮定している。シミュレーショ ンに用いた熱源モデルのパラメータとその值を Table 2 に 示す。

Fig.8に立向きマグ溶接の溶融池シミュレーションの一 例を示す。このシミュレーションでは、溶融金属の融点を

Table 2 Heat source variables used in numerical simulation (Image of spray transfer region)

\begin{tabular}{|l|l|}
\hline Total heat input & $6000 \mathrm{~W}$ \\
\hline Welding current & $200 \mathrm{~A}$ \\
\hline Radius of heat input distribution & $8.0 \mathrm{~mm}$ \\
\hline Peak value of arc pressure & $1000 \mathrm{~Pa}$ \\
\hline Radius of arc pressure distribution & $5.0 \mathrm{~mm}$ \\
\hline Arc length & $3 \mathrm{~mm}$ \\
\hline Wire diameter & $1.2 \mathrm{~mm}$ \\
\hline Wire feeding speed & $0.13 \mathrm{~m} / \mathrm{s}$ \\
\hline Frequency of droplet transfer & $100 \mathrm{~Hz}$ \\
\hline Drop temperature & $2800 \mathrm{~K}$ \\
\hline Drop speed & $100 \mathrm{~cm} / \mathrm{s}$ \\
\hline
\end{tabular}

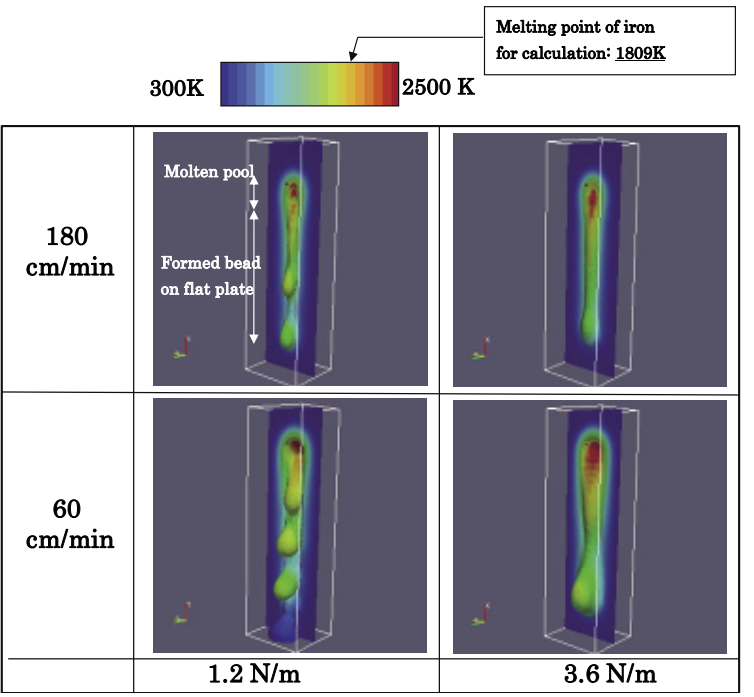

Fig.8 Numerical simulation of molten pool in vertical upward position by MAG welding. 


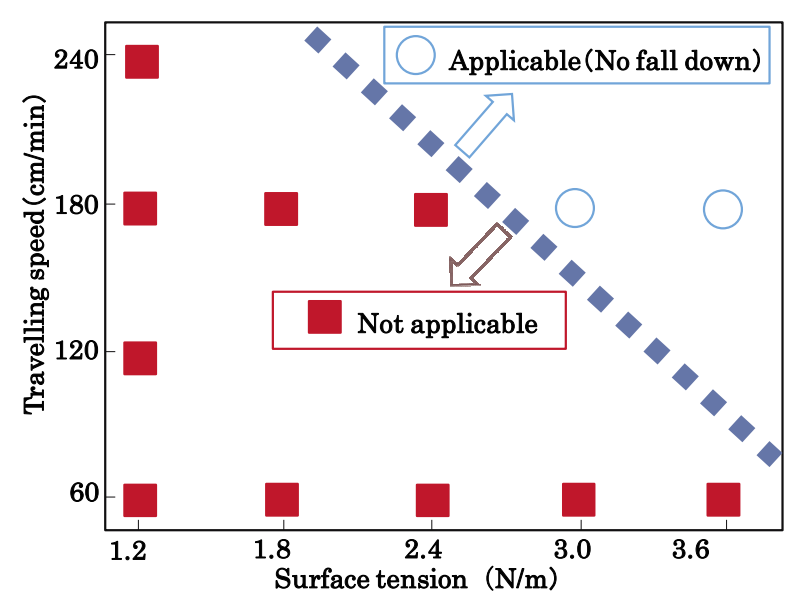

Fig.9 Feasible operation range of MAG welding in vertical upward position predicted by calculation.

純鉄の融点とほぼ同等とみなして $1809 \mathrm{~K}$ として算定し、ス ラグのない溶融池の状態を想定した計算を行っている。表 面張力の絶対值を $1.2 \mathrm{~N} / \mathrm{m}$ から $3.6 \mathrm{~N} / \mathrm{m}$ へと大きくすると、 表面張力による溶融池の支持力が高まる。さらに、溶接速 度を $60 \mathrm{~cm} / \mathrm{min}$ から $180 \mathrm{~cm} / \mathrm{min}$ へと大くすると、溶融池 サイズが小さくなるので、表面張力による懸垂能力が効果 的に働き、垂れ落ちが発生しなくなることを示す結果が得 られた。

上述のシミュレーションを表面張力： $1.2 \sim 3.6 \mathrm{~N} / \mathrm{m}$ 、溶 接速度: $60 \sim 240 \mathrm{~cm} / \mathrm{min}$ の範囲で行い、立向上進溶接が 可能な領域をまとめると、Fig.9に示すようになる。つまり、 スラグを形成しない溶融池を想定すると、200 A で立向上 進溶接を行うためには、計算上は溶接速度を $180 \mathrm{~cm} / \mathrm{min}$ 以 上にして溶融池を小さくするとともに、溶湯の表面張力の 絶対值を通常の溶融鉄の $2 \sim 3$ 倍以上に増加させる必要が あるという結果となった。すなわち、比較的大きな溶融池 を形成する中高電流域のグロビュール移行やスプレー移行 において、立向上進溶接を実施するためには、溶融金属だ けで溶融池を保持することは難しく、何らかの支える機構 が必須であるという結果となった。さらに、溶鋼の表面張 力の現実的な絶対值と照らし合わせても、また、溶接可能 な速度を考慮しても、スラグの形成なしに立向上進溶接を 実現する可能性は考え難い。以上のことから、立向上進姿 勢など全姿勢溶接を行うためには、表面張力による保持力 だけでは難しく、モールド効果のようなスラグによる溶融 池の保持作用が必要となることを明らかにできた。

\section{2 モールド効果の検証}

Fig.10に、チタニヤ系フラックス入りワイヤによる生成 スラグの主成分となる酸化チタン（試料：ルチル鉱石の粉 末, 分析雲囲気：大気）の熱特性と溶融池上のスラグ状況 を示す。1700 ${ }^{\circ} \mathrm{C}$ 近傍で TG（熱重量測定）の変化を伴わな

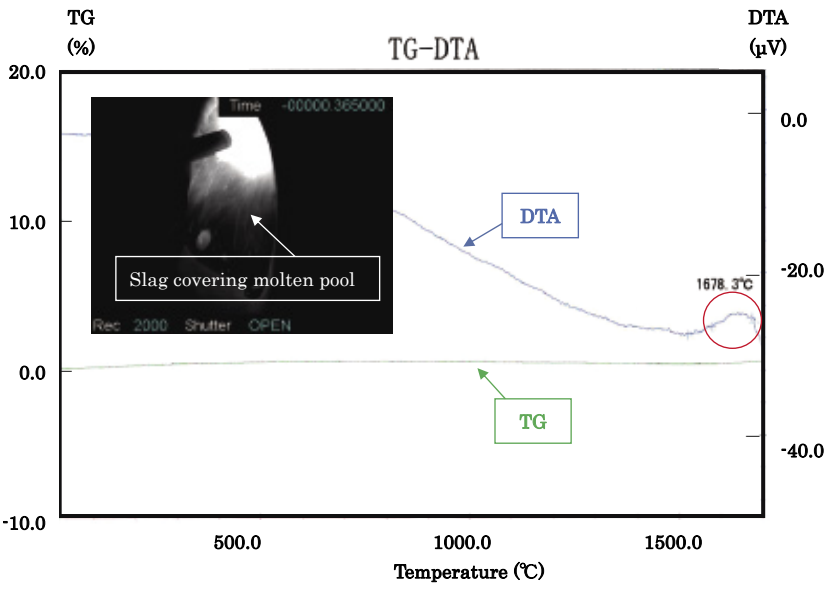

Fig.10 Differential Thermal Analysis of titanium oxide flux (Powder of rutile ore).

いDTA（示差熱）の発熱が認められた。この示差熱分析の 結果から、酸化チタンを主成分とするフラックスは $1700{ }^{\circ} \mathrm{C}$ 直下の温度域を融点·凝固点としており、溶融鉄の融点（約 $\left.1500{ }^{\circ} \mathrm{C}\right)$ よりも高くなっていることが確認できた、したがっ て、溶接時に溶融池に対してスラグ層が固相の鋳型として 作用し、溶融池を包み込んで、溶湯の垂れを抑えるモール ド効果を示すものと考えられる。

以上の考察を通して、溶融池の表面張力だけでは立向上 進姿勢での十分な懸垂力が得られず、溶接が不可能である ことが確認できた。一方で、チタニヤ系フラックス入りワ イヤの場合は、生成されるスラグが溶融池の垂れ落ちを防 ぐ支持効果を果たしていることを明らかにできた。

\section{3 溶滴移行の安定性}

Fig.11にフラックス入りワイヤの下向と立向の各姿勢に よるアーク中の観察例を示す。フラックス入りワイヤにお いては、フラックスを包む外皮金属部が、フラックスより も先に溶融する。4.2 項で述べたようにフラックスの融点 は外皮金属部よりも高いため、未溶融のフラックス成分が フラックス柱を形成し、ワイヤから溶融池に向かっている。 従来の研究成果として、Fig.11(a)のように下向溶接にお いては、溶滴はフラックス柱の表面を伝って先端に形成さ れ、鉛直下向に移行して溶融池に至ることが確認されてい る ${ }^{14)}$ 。溶滴はアーク反力によってワイヤ側に押し戻される ような場合もあるが、フラックス表面がガイドの役割を果 たして溶滴がフラックス柱の上にとどまって、吹き飛ばさ れることなく、安定して溶融池へと移行できる。本研究で は、Fig.11(b) に示す立向上進溶接の場合にも、下向溶接と 同様な形態で溶滴がワイヤ先端に生じ、溶融池へと移行し ていくことを確認した。したがって、フラックス入りワイ ヤでは、立向や下向といった溶接姿勢に関係なく、溶融金 属はワイヤから突き出たフラックス柱と溶融池との間で移 


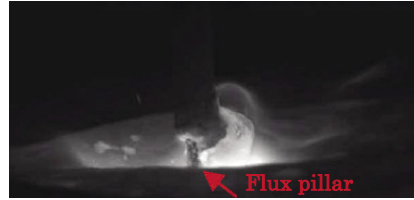

(a) Flat position $(1.2 \mathrm{~mm}$ in dia., $300 \mathrm{~A})$

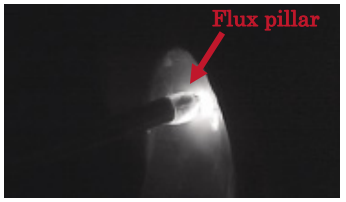

(b) Vertical upward position $(1.2 \mathrm{~mm}$ in dia., $190 \mathrm{~A})$

Fig.11 Flux pillar during flux cored arc welding.

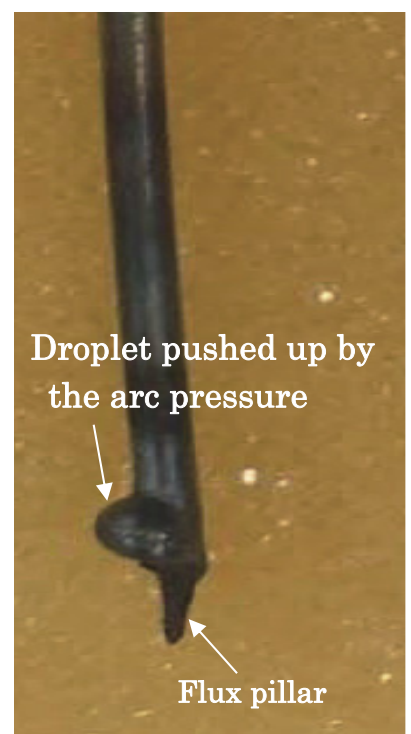

(a) Flux cored wire

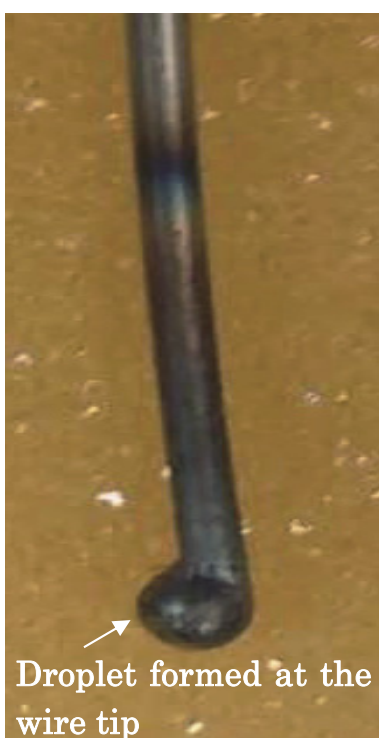

(b) Solid wire
Fig.12 Appearances of the wire tips after welding.

\section{行する。}

Fig.12に、チタニヤ系フラックス入りワイヤとソリッド ワイヤの消弧時のワイヤ先端部の外観を示す。フラックス 入りワイヤ先端に残ったフラックス柱と溶融金属の残留状 況からも、フラックス柱は溶融金属よりも融点が高く、酸 化物を中心とする高融点フラックス成分で構成されている ことが分かる。このため、姿勢溶接においても、溶融した 外皮金属が確実に溶融池への移行することが可能となり、 アーク現象が安定になると考えられる。

\section{5. 結言}

チタニヤ系フラックス入りワイヤとソリッドワイヤを用 いたマグ溶接について、立向上進姿勢における溶接可能条 件を調べた。溶滴移行並びに溶融池を高速度ビデオにより 観察し、姿勢溶接における溶融池保持に関して検討 · 考察 した。以下に得られた結果を要約する。

(1) チタニヤ系フラックス入りワイヤは、立向上進姿勢に
おいて、ソリッドワイヤに比較すると、垂れ落ちやハ ンピング、アンダーカットなどの溶接欠陥が生じない 溶接条件範囲が圧倒的に広い。

(2) チタニヤ系フラックス入りワイヤを用いた溶接におい ては、溶融池表面に溶湯を覆って鋳型のような役割を 果たす高融点スラグが存在する。このスラグ層によっ て、溶湯の垂れ落ちが防止される。

(3) チタニヤ系フラックス入りワイヤは、溶接姿勢によら ず溶接時にワイヤ先端にフラックス柱を形成する。ワ イヤ外皮の溶融金属は、フラックス柱に沿って、溶融 池へ安定して移行する。

\section{謝 辞}

本研究にあたり、ご協力やご助言いただいた (一社) 日本 溶接協会と(株)神戸製鋼所に対しまして、厚く御礼申し上げ ます。

\section{参考文献}

1) Y.Sakai ;New GMAW wires coming from Japan, Welding design \& fabrication, 4 (1992) 40-48.

2) Y.Sakai, I.Aida, T.Suga, T.Nakano ;Development of various fluxcored wires, IIW Doc.,XII-1131-89(1989).

3) T.Suga; Welding consumables, Journal of the Japan welding society, 67-8 (1998) 38-55.

4) F.Koshiishi; Welding materials, Journal of the Japan welding society, 72-2 (2003) 16-19.

5) 日本溶接材料工業会編；溶接材料生産 - 出荷実績、溶接展望、 109 (2015) 5.

6) T.Suga, M.Kobayashi ;Droplet transfer phenomena in $\mathrm{CO} 2$ arc welding by flux-cored wire, Quarterly journal of the Japan welding society, 3-2 (1985) 269-276.

7) Y.Sakai, K.Hosoi, K.Ikemoto, T.Suga; The recent situation of flux-cored wire for MAG welding in Japan, The seminar on producers' and users' metallurgical requirements in the welding of steel products, United Nations Economic Commission for Europe,(1990),AnnexI R.21.

8) F.A.Halden, W.D.Kingery; J.Phys. Chem., 59 (1955) 557.

9) W.vor dem Esche, O.Peter; Arch.Eisenhuttenw., 27 (1956) 355.

10) P.Kozakevitch, G.Urbain; Mem.Sci.Rev.Met., 58 (1961) 517.

11) K.Hosoi, Y.Hirata; Influence of alloying elements on the toughness of the weld metal by the titania-based flux cored wire, To be published.

12) K.Hosoi, Y.Hirata; Influence of microstructures on the toughness of the weld metal by the titania-based flux cored wire, To be published.

13）荻野、平田：継手形状・溶接姿勢を考慮した 3 次元溶融池モ デル、溶接学会平成 27 年春季全国大会講演概要集、第 96 集、 p142-143.

14) I.Yen; アーク溶接の溶滴移行について、神鋼技術レポート、 54-1 (2014). 